\title{
Osmanlı Düşüncesi, Kaynakları ve Tartışma Konuları Sempozyumu
} (18-19 Ekim, Sakarya)

\author{
Metin AYDIN*
}

İslam Düşünce geleneğinin mütemmim cüzü olmakla birlikte farklı düşünce geleneklerinin de varisi olarak kabul edebileceğimiz Osmanlı düşüncesi, içinde neşet ettiği imparatorluğun dünya tarihindeki etkinliğinin aksine hakkında oldukça az malumata sahip olduğumuz bir alan olarak karşımıza çımaktadır. Osmanlı düşüncesi hakkındaki çalışmaların azlığından kaynaklanan malumat eksikliği günümüzde iki farklı yaklaşımın temel dayanağı haline gelmiştir. İslam düşüncesini kendisine çalışma alanı olarak seçmiş akademisyenlerin bir kısmı söz konusu dönemdeki yazım geleneğinin ağırlıklı olarak temel metinlere yazılan şerh ve hâşiyelerden oluşmasından hareket ederek, Osmanlı düşüncesinin tevarüs ettiği geleneğe herhangi özgün bir katkısı olmadığını iddia etmektedirler. Bu görüşe karşı olan akademisyenler ise bahse konu olan şerh ve hâşiyelerin aslında özgün birer akademik üretim olduğunu ve birçok noktada temel metinlere yeni meydan okumalar olarak değerlendirilmesi gerektiğini savunmaktadırlar. Bu akademisyenlere göre, Osmanlı düşüncesi birçok özgün fikrin neşet ettiği yeni bir gelenek olarak okunmalıdır. Osmanlı düşüncesine ait çalışmalar göz önüne alındığında hangi tarafın görüşlerinde haklı olduğu konusunda karar vermek için oldukça erken olduğu söylenebilir. Bu konuda nihai bir karara varmak, mezkûr düşünce geleneğine yönelik çalışmaların tatmin edici niteliğe ve niceliğe ulaşmasının ardından mümkün olacaktır.

Tanıtımını yapacağımız “Osmanlı Düşüncesi, Kaynakları ve Tartışma Konuları" başlığını taşıyan sempozyum, kısa adı OSAMER olan ve müdürlüğünü Prof. Dr. Fuat Aydın'ın yaptığı Sakarya Üniversitesi Osmanlı Araştırmaları Merkezi tarafından, 18-19 Ekim 2017 tarihinde Sakarya Üniversitesi Kongre Merkezinde gerçekleştirildi. Çağrı metninde sempozyumun şu iki amaç doğrultusunda düzenlendiği ifade edilmektedir: (1) Osmanlı'nın Klasik Dönemi olarak adlandırılan XIV-XVIII. yüzyıl Osmanlı düşüncesinin kendisini ifade ettiği, izinin takip edileceği ve bulunmak istendiğinde başvurmanın zorunlu olduğu eserlerin tespiti ve tanıtımı, (2) Osmanlı düşüncesinde ön plana çıkan tartışma konularının tespiti.

\footnotetext{
* Arş. Gör., Sakarya Üniversitesi İlahiyat Fakültesi Felsefe Tarihi Anabilim Dalı ve Sakarya Üniversitesi Sosyal Bilimler Enstitüsü Doktora Öğrencisi

(metina@sakarya.edu.tr)
}

DOI: http://dx.doi.org/10.17335/sakaifd.346381

Geliş T. / Received Date: 25/10/2017

Kabul T. / Accepted Date: 08/11/2017 
Sempozyumda iki gün boyunca iki salonda toplam 15 oturumda 51 bildiri sunulmuştur. Bu bildiriler iki ayrı salonda gerçekleştirildiği için bu yazıda bildirilerin tamamına yer verilemeyecektir.

Sempozyumun ilk gününde açllış oturumundan önce protokol konuşmaları yapıldı. Sırasıyla OSAMER başkanı Prof. Dr. Fuat Aydın sempozyum ve OSAMER'in faaliyetleri hakkında katılımcılara ve dinleyicilere kısa bir sunum yaptı. Ardından sırasıyla Sakarya Üniversitesi İlahiyat Fakültesi Dekanı Prof. Dr. Ahmet Bostancı, Sakarya Üniversitesi Rektör Yardımcısı Prof. Dr. Musa Eken ve son olarak da Yazma Eserler Kurumu Başkanı Prof. Dr. Muhittin Macit birer selamlama konuşması yaptılar. Protokol konuşmalarının ardından aynı salonda oturum başkanlığını Prof. Dr. İlhan Kutluer'in yaptığı “Osmanlı Düşüncesinin Üzerine Oturduğu Entelektüel Bağlam: 13. yüzyılda Fıkıh, Tasavvuf, Kelâm ve Felsefe" başlıklı oturum gerçekleştirildi.

Açılış oturumunun ilk sunumu Prof. Dr. Murtaza Bedir tarafından yapıldı. Sunumunda Osmanlı fıkıh geleneğinin oluşum sürecini ve beslendiği kaynaklardan bahseden Bedir, konuşmasına önemli bir tespitle başladı. Bedir'e göre Osmanlı düşüncesi ile mirasçısı olduğu ilmi gelenek arasında herhangi bir kopukluk olmamasına rağmen, başta Türkiye olmak üzere diğer Osmanlı mirasçısı ülkeler varisi oldukları bu geleneği tevarüs etme konusunda sıkıntılar yaşamışlardır ve bu sıkıntılar halen de devam etmektedir. Bu durumun en önemli nedeni Batı düşüncesinde ortaya çıkan modernitenin, Batı dışındaki toplumlara geleneklerinden kurtulmaları gerektiğine ilişkin yaklaşımını kabul ettirmeyi başarmış olmasıdır. Bu kabulün en önemli sonucu ise gelenekte özgün herhangi bir şeyin olmadığı bilincinin mezkûr toplumlardaki akademisyenler tarafından benimsenmesi olmuştur. Bu önemli tespitin ardından Bedir, Osmanlı fıkıh düşüncesinin İslam fıkıh geleneğini nasıl tevarüs ettiği meselesi üzerinde durdu. Osmanlı fıkıh düşüncesi açısından 12. 13. ve 14. yüzyıllar önemli asırlar olmakla birlikte Osmanlı fıkhı özgün üretimlerini 15. yüzyılın ikinci yarısından itibaren vermeye başlamıştır. Bununla birlikte özgün anlamda fıkıh âlimlerinin ortaya çıkışı içinse 16. yüzyılı beklemek gerekmiştir. Bu dönemde Fetevâ türü eserler Türkçe olarak kaleme alınmaya başlanmıştır. Bedir'e göre Osmanlı fıkhının oluşumunda iki ana damar etkili olmuştur. Bu damarlardan ilki, Mâverâünnehr'de üretilen, temsilciliğini Serahsî ve Pezdevî'nin yaptığı Mâtürîdî-Hanefî fıkıh usûlü geleneğidir. Düşünsel damar olarak isimlendirilebilecek bu geleneğin Osmanlı coğrafyasına gelişi, 12. yüzyılın sonları 13. yüzyılın başlarında ortaya çıkan Moğol istilasının neden olduğu göç hareketi vasitasıyla olmuştur. Bu gelenek Mâverâünnehr'den göç eden âlimler tarafından ilk olarak Şam ve Kahire'ye oradan da Anadolu'ya ulaştırılmıştır. Bu göç dalgası âlimlerle birlikte temel eserlerin de Osmanlı ilim havzasına ulaşmasına vesile olmuştur. 11. yüzyıldan itibaren 
Memluk coğrafyasında zamanla Eşârîliğin güçlenmesi ve Mu'tezilenin kaybolması, Şam, Bağdat, Kahire coğrafyasında Cüveynî, Gazzâlî, Râzî gibi büyük âlimlerin gayretleriyle Eşârîliği hâkim gelenek haline getirmiştir. Dolayısıyla bahsi geçen coğrafyalar 13. yüzyıldaki göç dalgası Eşârî fıkıh geleneği ile Mâtürîdî-Hanefî fıkıh geleneğinin yüzleştiği ilim havzaları haline gelmiştir. Osmanlı fikhını oluşturan gelenek bu yüzleşmeden geçerek Anadolu'ya ulaşmıştır. Bu yüzleşmede Mâverâünnehr fikıh geleneğini etkileyen en önemli unsur, kendi coğrafyasında karşılaşmadığ1 Eşârî kelâmıyla karşılaşması ve Şam, Bağdat, Kahire coğrafyasındaki oldukça ileri düzeydeki Hadis çalışmalarından haberdar olması olmuştur. Bu karşılaşmanın sonucu olarak Mâtürîdî-Hanefî gelenek Serahsî ve Pezdevî'nin fikıh usûlü anlayışını Râzî geleneği ile mezcetmeye girişmiştir. Bu mezcin en önemli ürünleri olarak İbn Sââtî'nin Bedîu'n-nizâm ve Sadruşşerîa es-Sânî'nin'nin et-Tenkîh ve et-Tavzîh adlı eserleri görülebilir. Bu eserlerden et-Tavzîh Osmanlı medreselerinin başat kitaplarından biri haline gelmiş ve fıkıh çalışmalarını şekillendirmiştir. Bedir'e göre Osmanlı fıkhını oluşturan ikinci damar ise Osmanlı fıkıh âlimlerinin kendilerinin oluşturduğu damardır. Osmanlı fıkıh âlimleri Mâverâünnehr'den kendilerine ulaşan Mâtürîdî-Hanefîliği büyük ölçüde muhafaza etmişlerdir. Bedir'e göre Hanefî fıkhı düşünsel temelde kendisini değiştirse de özellikle fürû fıkhında ortaya çıktığ 1 8. ve 9. yüzyıldan itibaren İmam-1 Azam çizgisini ifade eden Ehl-i Rey geleneğini muhafaza etmeyi başarmıştır. Hanefî fıkıhçılar özellikle 10. yüzyıl ile birlikte Ehl-i Hadis'in bu alandaki baskınlığından çok fazla etkilenmemişlerdir. Bu durumun en önemli etkenlerinden birisi Hanefî fıkhının yeni problemlere çözüm üretme noktasındaki işlevselliğinin yönetime sahip olanlar tarafından kullanılmak istenmesi ve bunun sonucunda da Hanefî fıkıh âlimlerinin devlet tarafından korunmasıdır.

Oturumun ikinci konuşmasını Prof. Dr. Ekrem Demirli yaptı. Demirli, sunumunda Osmanlı ilim geleneği ile İbn Arabî'nin kurucusu olduğu tasavvuf metafiziği diyebileceğimiz düşünce geleneği arasındaki ilişkiyi ele aldı. Demirli'ye göre İslam dünyasında h. 6. ve 7. yüzyıllarda kurumsal medreselerin ve eğitim kurumlarının teşekkül etmesiyle birlikte tarikatlar de yaygınlaşmış ve ilk büyük tasavvuf hareketleri tarih sahnesine çıkmaya başlamışlardır. Bu anlamda Demirli'ye göre medreseler ile tekkelerin yaygınlaşması arasında bir ilişkiden bahsedilebilir. Büyük tasavvuf hareketlerinin ortaya çıkardığı en önemli ürün teorik tasavvuf düşüncesi olmuştur. Demirli, Osmanlı tasavvuf düşüncesini konuşmak isteyen birinin hareket noktasının bu büyük tasavvuf hareketleri olamayacağını ifade etti. Ona göre Osmanlı tasavvuf düşüncesi İbn Arabî ve geleneğin devam ettiricisi Sadreddin Konevî üzerinden okunmalıdır. İbn Arabî ve Konevî’yi anlamak için de Gazzâlî'nin el-Munkız'da kelâmcıları ve felsefecileri eleştirirken kullandığı ifadeleri dikkate almak ge- 
rekir. Gazzâlî, el-Munkız'da kelâmcıları yetersiz, felsefecileri de tutarsız bulduğunu söyler. Demirli'ye göre İbn Arabî ve Konevî, Gazzâlî́nin bu eleştirisini tersine çevirerek, felsefecilerin yetersiz, kelâmcıların da tutarsız olduğunu söylemişlerdir. Bu yaklaşım, eleştirilerin felsefeciler üzerinden kelâmc1lara kaymasına neden olmuştur. İbn Arabî geleneği buradan hareketle yeni bir düşünce inşa etmeye çalışmıştır. Bu inşa faaliyetinin ana ürünü Vahdet-i Vücûd düşüncesi olmuştur. İbn Arabî ve Konevî'nin bu yaklaşımı Râzî sonrası dönemde kelâma önem veren düşünce geleneği ile ters düşmesine neden olmuştur. Doğası gereği bu yeni düşüncenin kelâmla barışması da mümkün değildi. Çünkü bu yeni metafizik düşünce Tanrı'nın ispatlanması, âlemin hâdisliği gibi kelâmın ana konularının işlerliğini ortadan kaldırmıştır. Demirli'ye göre kelâm ile ters düşmek aslında Osmanlı düşüncesini besleyen ana damarlardan biri ile ters düşmek anlamına gelmiştir. Bunun doğal sonucu olarak da medreselerde kelâm etkili olduğu için İbn Arabî'nin oluşturduğu düşünce geleneği medreselere girememiştir. Demirli'ye göre mutasavvıf kişiliği ile ön plana çıkmış ve Osmanlı ilim geleneğinde etkili olmuş kişilerden hareket ederek bu iddianın aksinin savunulması fazla iyimserliktir. Bu iddiaya karşı çıkanların örneklerinden birisinin Molla Fenârî olduğunu söyleyen Demirli, Molla Fenârî́nin Misbâhu'l-üns ve ona yazdı̆̆ı şerhi ahir ömründe yazdığını, bu eserlerde de yaptığı şeyin bir açıdan literatür özetinden ibaret olduğunu belirtti. Dolayısıyla Demirli bu anlamda onun İbn Arabî geleneğinin medreselerdeki önemli ve etkili bir temsilcisi gibi görmenin yanlış olacağını savundu. Benzer bir durumun Dâvûd-i Kayserî için de geçerli olduğunu söyleyen Demirli, Osmanlı ilim geleneğinin İbn Arabî tarafından üretilen metafizik düşünce ile ilişkisinin problemli olduğunu belirtti. Bunun en temel nedeni de Osmanlı ilim geleneğinin tercihini kelâmdan yana kullanmış olmasıdır. Demirli'ye göre medreselere giremeyen tasavvufî düşünce edebî şiirlerde, bazı Melâmî gruplarda ve daha az ilmî olan meclislerde kendisini izhâr etmiştir. Demirli bildirisinin son kısmında İbn Arabî'nin Osmanlı mutasavvıfları üzerindeki etkisine değindi. Ona göre İbn Arabî’nin görüşlerinin tasavvufî düşünce geleneğinin ana paradigması haline geldiği için kendisinden sonra neşet eden bütün tasavvufî düşünceler bu paradigma temelinde yorumlanmıştır. Osmanlı mutasavvıfları Dâvûd-i Kayserî, Cendî gibi âlimlerin görüşlerini eleştirmelerine rağmen İbn Arabî'nin bu otoritesini asla tartışma konusu yapmamışlar, İbn Arabî'ye rağmen bir düşünce teorisi ortaya atmamışlardır. Bu bağlamda Osmanlı'da oldukça yaygın olan Fususu'l-Hikem şerhlerine bakıldığında ana teoriye ilişkin herhangi bir eleştiri ya da katkı görememek Demirli'ye göre büyük hayal kırıklı̆̆ı yaratır. Sonuç olarak İbn Arabî’nin otoritesinin tasavvufî yorumların doğruluk standardı haline geldiğini söylemek Demirli'ye göre hiç de abartılı olmayan bir yorumdur. Demirli bu önemli tespitiyle bildirisine son verdi. 
Prof. Dr. Ekrem Demirli'nin konuşmasının ardından oturumun 3. sunumu Doç. Dr. Eşref Altaş tarafından gerçekleştirildi. Altaş konuşmasında 13. yüzyılda etkili olan kelâmcılara, bu dönemdeki kelâm geleneklerinin genel durumlarına ve özellikle Râzî sonrası dönemde kelâm ile felsefe arasında gerçekleştiği ileri sürülen mezc iddiasına değindi. Altaş sunumuna ilk olarak 13. yüzyılda yaşamış ve Osmanlı kelâmî düşüncesini etkilemiş olan mütekellimleri zikrederek başladı. Eşârî gelenek içerisinde yer alan Râzî, Âmidî, Urmevî, Beyzâvî, - her ne kadar 14. yüzyılda yaşamış olsalar da Îcî, Teftâzânî, Cürcânî gibi isimler de etkileri açısından bu isimler arasında zikredilebilir- gibi önemli kelâmcılar Osmanlı kelâm düşüncesinde etkili olmuşlardır. Bununla birlikte Altaş 13. yüzyılda yaşamış olan ve Osmanlı düşüncesini etkileyen Mâtürîdî geleneğe mensup kelâmcıların sayısının fazla olmadığını belirtti. Bu isimler arasında sayılabilecek en önemli kelâmcı olarak el-Umde yazarı Ebü'l-Berekât karşımıza çıkar. Altaş'a göre Eşârî ve Mâtürîdî kelâmcılara ek olarak Tûsî ve Allâme Hillı̂́nin de Osmanlı kelâm geleneğini etkileyen mütekellimler arasında sayılması gerekir. 13. yüzyıl kelâmı için yapılabilecek en önemli tespit bu dönemde özellikle Gazzâli'yle başlayan bir sürecin sonucunda Râzî ile birlikte kelâmda önemli bir dönüşüm yaşanmış olmasıdır. Gazzâli'ye kadar olan dönemde kelâm daha çok İslam toplumundaki gayri Müslimlere İslam'ı savunmak şeklinde bir misyon edinmişken, Gazzâlî ve sonrasında Râzî ile birlikte bir dönüşüm yaşayarak felsefe ile ciddi etkileşim içine girmiştir. Bunun en temel nedenlerinden biri mütekellimûn ve felâsifenin Gazzâlî sonrası dönemde aynı ilim meclislerinde yer almaya başlamış olmalarıdır. Aynı ortamı paylaşmanın doğal sonucu ise her iki tarafın da belirli meseleler üzerinde taraf olmaları olmuştur. 13. yüzyılda Râzî sonrası dönemde bu etkileşim daha da artarak, daha önce aynı meclisi paylaşan kelâmcılar ve felsefeciler artık aynı eserleri paylaşmaya başlamışlardır. Buraya kadar yapılan tespitler daha çok Eşârî kelâmı için geçerlidir. Benzer bir dönüşümün Mâtürîdî gelenek içerisinde yaşandığını söylemek, Altaş’a göre şu anki bilgilerimiz temelinde mümkün gözükmemektedir. Bu iddianın gerekçesi ise Eşârî eserlerinde yaşanan dönüşümün Mâtürîdî eserlerde görülmemesidir. Bu dönemdeki Mâtürîdî kelâm eserleri atıflarını hala İslam düşüncesinin ilk dönemlerinde karşımıza çıkan Berâhime, Mazdekizm gibi düşünce geleneklerine yapmaktadırlar. Altaş'a göre enteresan şekilde İbn Sinâ'nın eserlerine şerh yazma geleneği de kelâmcilar üzerinden yürümüştür. Râzi, Tûsî, Hillî gibi şahsiyetler söz konusu bu şerh geleneğinin en önemli kelâmcı simaları olarak dikkat çekerler. Fakat aynı durumun Mâtürîdî gelenek için geçerli olduğunu söylemek mümkün değildir. Altaş 13. yüzyıl kelâm düşüncesine dair bu genel girişten sonra, günümüzde de sıkça dillendirilen mezc iddiasını tartışmaya geçti. Günümüzdeki kelâm eserlerinde kullanılan "memzûc dönem”, "felsefî kelâm” gibi kullanımlar genel itibariyle felsefe ile kelâmın iç içe geçtiğini, bir anlamda kelâmın felsefîleşirken felsefenin de kelâmlaştığını ima eder. Altaş'a göre bu 
iddianın temel dayanağı olarak genelde karşımıza İbn Haldun çıkar. İbn Haldun eserinde Eşârî kelâmında bir mezcin olduğundan bahseder. Buna göre belli bir noktadan sonra felsefe ile kelâmın konuları aynılaşmıştır. Günümüzde İbn Haldun'un kastettiği bu mezc için "İkinci Klasik Dönem, Yenilenme, Yeni Eşârîcilik, vb. gibi" isimlendirmeler kullandığımızı ifade eden Altaş'a göre bahse konu olan mezcin gerçekte ne anlama geldiğini daha iyi anladığımız vakit bu isimlendirmelerin gözden geçirilmesi ihtiyacı ortaya çıkacaktır. İbn Haldun'a göre mezc ilk olarak yöntemde kendini göstermiştir. İlk dönem Eşârî kelâmcıları fıkıhçılarla birlikte şâhidin gâibe kıyası yöntemini kullanmışlardır. Bu yöntem Cüveynî, Gazzâlî ve Râzî tarafından dayandığı ontolojik temel açısından sorgulanmıştır. Bu sorgulamanın temel iddiası birbirleriyle ontolojik açıdan benzerlik göstermeyen iki varlık alanının birbirlerine şahit gösterilerek kıyas edilmesidir. Buradaki problemin kaynağı atomculuktur. Çünkü kelâmcılara göre varlık ister kesif olsun ister latif olsun atomlardan oluşur. Fakat Tanrı'nın kendisi için bu geçerli değildir. Dolayısıyla atomlardan oluşan bir ontolojik düzlemden hareket ederek atomdan oluşmayan bir varlık hakkında konuşmak mümkün değildir. Bununla birlikte nedenselliğin inkârı da şâhidin gâibe olan kıyasını imkânsız hale getirmektedir. Altaş'a göre bu yöntem eleştirisi metot olarak nazar ve keşfin kelâm düşüncesinde dâhil olmasıyla sonuçlanmıştır. Bu aşamadan sonra artık kelâmcılar felsefeden alınan mantık ilminin tedrisine başlamışlar ve mantığa dayalı olarak argümantasyonun nasıl işletileceğine dair çalışmalarının sonucunda da "Âdâbü'l-bahs ve'l-münâzara" ilminin kurulmasına önayak olmuşlardır. Kısacası Altaş’a göre mezcin ilk ayağını bu yöntem ithali oluşturur ve bu bağlamda yöntem açısından kelâm ile felsefe arasında bir mezcin olduğuna ilişkin iddia makuldür. İbn Haldun'un bahsettiği ikinci mezc, mesâil alanı ile ilgilidir. Altaş'a göre bahsi geçen dönemde kelâm eserlerinin konu düzeninde ve içeriklerinde bir farklılaşmanın olduğu bir gerçektir. Üçüncü mezc ise kavramlarla ilgilidir. Bu dönemde kadîm, hâdis, varlık, mahiyet, zorunlu, mümkün gibi kavramlar kelâmcılar tarafından da kullanılmaya başlanmıştır. Ancak Altaş'a göre bu zikredilen kavramlar ve bunlara ek olarak zaman, mekân, hareket, vb. gibi kavramların kullanımı noktasında kelâmcılar ile felsefeciler arasında bir fark vardır. Kelâmcıların bu kavramları İbn Sînâcı gelenekte kullanıldığı şekilde kullanmamışlardır. Kelâmcılar bu kavramları itibârî olarak kullandıkları için bahse konu olan bu kavramların felsefeden ithali kelâm açısından ontolojik problemler ortaya çıkarmamıştır. Bir başka deyişle kelâmcılar bu kavramları îtibârî olarak kabul etmek suretiyle kavramların ontolojik yüklerinden kurtulmayı başarmışlardır. Dolayısıyla şekilsel olarak felsefeciler ve kelâmcılar arasında karşımıza çıkan kavramsal birliktelik içeriksel açıdan oldukça farklıdır ve bu anlamda bir mezcden söz etmek mümkün değildir. Altaş bunlara ek olarak felsefenin kelâm tarafından araçsallaştırıldı̆̆ın- 
dan bahsedilebileceğini söyledi. Buna göre kelâm özellikle İsbât-ı Vâcib konusunda felsefenin Tanrı kanıtlamalarından yararlanmıştır. Altaş'a göre tüm bunlardan hareketle sorulması gereken asıl soru şudur: "Yöntemsel, içeriksel ve kavramsal birliktelik gerçekten bir mezci ifade eder mi?" Bu sorunun olumsuz olarak cevaplanması gerektiğini ifade eden Altaş'a göre felsefe ve kelâm günümüzde kullanıldığı anlamıyla asla bir birliktelik içinde olmamışlardır. Altaş bu düşüncesinin temel gerekçesi olarak İbn Sînâ şârihi olarak kabul edilebilecek olan Tûsî, Râzî, Âmidî gibi kelâmcıların asla Tanrı'nın fiillerinde özgür bir fail olduğu inancından vazgeçememelerini gösterdi. Yine âlemin ezelî oluşu konusunda, sudûr teorisini reddetmek konusunda, nefsin mücerred olduğunu reddetme konusunda, göksel akılları reddetme konusunda ve daha birçok konuda İbn Sînâ geleneğine karşı çıkma noktasında neredeyse bütün kelâm geleneğinin oldukça istekli olması Altaş'ın bu sorunun olumsuz olarak cevaplanması için dayandığı diğer gerekçeleri oluşturur.

Açılış oturumunun son konuşmacısı Doç. Dr. Mustakim Arıcı'ydı. Konuşmasında Osmanlı düşünce geleneğinin kurucu metinlerini besleyen felsefî literatüre odaklanan Arıcı, sunumun hemen başında birkaç hususun altını çizdi. Bu hususlardan ilki, sunumun süresi gereği sunacağ literatürün daraltılmış bir literatür olduğu, dolayısıyla tıp, astronomi, matematik, doğa bilimleri, vb. gibi eserlerin sunum dışı bırakılmış olduğuydu. Literatürün daraltılmasına ilişkin ikinci husus İbn Sînâ geleneğini devam ettiren el kitabı mahiyetindeki metinlerin matematik ilimleri dışarıda tutması ve geleneğin daha çok metafizik ve fiziğin ilgili konular üzerinden yürümesidir. Arıcı daraltılmış olan literatürü iki açıdan tasnif ettiğini belirtti. Buna göre ilk tasnif doğrudan Antik dönem düşünürleri özellikle Platon ve Aristoteles'e ait metinler üzerinden yapılan tasnif, diğeri ise Osmanlı öncesi metinler (800-1300) ile Osmanlı döneminde, 14. yüzyıl ve sonrasında yazılıp Osmanlı coğrafyasına intikal eden metinler üzerinden yapılan tasniftir. Arıcı ilk tasnife geçmeden önce bahse konu olan metinlerin Osmanlı düşüncesine intikalinin de üç yolla gerçekleştiğini belirtti. (1) İlhak edilen beylikler ve devletlere ait coğrafyalardaki vakıf kütüphanelerinde bulunan metinlerin merkeze taşınması. (2) Hareket halindeki ulemânın yanında getirdiği metinler. (3) Sahafların getirdiği ya da siparişle getirilen metinler. Metinlerin intikal yolunu kısaca ifade ettikten sonra tekrar literatüre odaklanan Arıcı, ilk tasnif temelinde Osmanlı kütüphanelerinde bulunan metinlerin daha çok Platon ve Aristoteles'e ait olan apokrif metinler olduğunu belirtti. Söz gelimi, Aristoteles'e atfedilen Sırru'lesrâr adlı apokrif metnin 30'a yakın nüshasını kütüphanelerde bulmak mümkündür. Bununla birlikte Galen, Osmanlı kütüphanelerin en çok eseri bulunan Antik dönem düşünürü olarak karşımıza çıkar. Arıcı, ikinci tasnifi ise iki açıdan ele aldı. İlk olarak medrese kaynaklı metinlerden bahseden Arıcı, bu konuda özellikle Hidâyetü'l-hikme ve Hikmetü'l-ayn'ın dikkat çekici metinler 
olduğunu belirtti. Bu iki metnin müfredatta olması yoğun bir ilgiye mazhar olmalarını sağlamıştır ve bu konuda hacimli bir literatürden bahsetmek mümkündür. İkinci olarak ise ulemanın müfredat dışında okuduğu ya da entelektüel merakı olan çevrelerin iltifat ettiği metinlerden bahsedilebilir. Özellikle medrese müfredatında yer almasa da okutulan metinler olarak İbn Sînâ'nın el-Işârât ve'tenbihât, eş-Şifâ, en-Necât, Uyûnü'l-hikme gibi eserleri, Gazzâli ve İbn Rüşd'ün Tehâfütleri ve üzerlerine yazılan şerhleri, Sühreverdî ve İşrâkî metinleri ve bunlar dışında Kindî, İhvân-ı Safâ, Ebû Bekir er-Râzî, Belhî, Fârâbî, İbn Tufeyl, İbn Bacce, İbn Rüşd gibi filozofların metinleri ve risâleleri zikredilebilir. Arıcı bahsi geçen eserlerin Osmanlı felsefi düşüncesini nasıl inşa ettiğine temas ederek sunumunu nihayete erdirdi.

Açılış oturumundan sonra Salon 2'de gerçekleştirilen I. Oturuma Prof. Dr. Muhittin Macit başkanlık etti. Üç katılımcının yer aldığı oturum Prof. Dr. Gürbüz Deniz'in “İlk Varlığın Cins ve Fasla Bölünemeyeceği Hakkında” başlıklı sunumuyla başladı. Deniz, sunumunda Gazzâlî’nin meşhur eseri merkezinde oluşan Tehâfütler geleneğinde yedinci mesele olarak ele alınan, Tanrı'nın tanımının yapılıp yapılamayacağına ilişkin filozoflar ve mütekellimler arasındaki tartışmanın Osmanlı düşüncesindeki yankılarına değindi. Deniz'den sonraki ikinci konuşmacı olan Yrd. Doç. Dr. Mehmet Aydın ise "Zihnî Varlığın Aslî Varlık Oluşu: İbn Kemal Paşa ve Taşköprülüzâde Arasında Bir Tartışma" başlıklı bildirisini sundu. Aydın, başlıktan da anlaşılacağı üzere tebliğinde İbn Kemal ve Taşköprülüzâde arasında cereyan eden zihnî varlığın asıl varlık mı gölge varlık mı olduğuna ilişkin tartışmayı ele aldı. Dış dünyadaki varlığın zihinde canlanan suretinin gölge varlık, ondan soyutlanarak elde edilen mahiyetin aslî varlık olduğunu iddia eden İbn Kemal'e, Taşköprülüzâde dış dünyadaki varlığın asıl varlık olduğu iddiasılyla karşı çıkmıştır. Bu noktada Aydın önemli bir hususun altını çizerek İbn Kemal ile Taşköprülüzâde arasında dış dünyadaki varlığın aslîliği konusunda herhangi bir tartışma olmadığını belirtti. Dolayısıyla tartışmanın sadece zihnî varlığa ilişkin olduğunu ifade eden Aydın, tartışmanın ontolojik düzlemde değil, epistemolojik düzlemde cereyan ettiğini ileri sürdü. Bu bağlamda Aydın’a göre İbn Kemal, zihnî varlığın aslîliğgini savunarak felasife tarafında, Taşköprülüzâde ise bunu reddederek mütekellimûn tarafında yer almıştır. Oturumun üçüncü ve son katılımcısı Arş. Gör. Hacer Ergin ise "Celâleddin Devvânî'nin Nefsü'l-emr Anlayışı" başlıklı sunumunu dinleyiciyle paylaştı. Nefsü'l-emr kavramının İslam düşünce geleneğinde küllî akıl, faal akıl gibi kavramlarla ele alındığını ve felsefi bir problem olarak ilk defa Nasîrüddin Tûsî ile ortaya çıtığının söylenebileceğini belirten Ergin, Tûsî'nin meseleyi Risâle fî isbâti'l-akli'l-mücerred adlı risâlede ele aldığını ve tartışmayı mutâbakat kavramı üzerinden yürüttüğünü belirtti. Ergin'e göre Tûsî'nin meseleye bakışı birçok düşünürü etkilemiş 
ve bu mesele üzerine bir literatür oluşmuştur. Bu mesele üzerine düşüncelerini ifade edenlerden biri de Celâleddin Devvânî'dir. Ergin bildirisinde Devvânî'nin Tûsî'nin nefsü'l-emr anlayışına ilişkin yaklaşımlarına temas etti. Ergin'e göre, Tûsî'nin bahsi geçen risâlesine yazdiğı Şerhu risâleti isbâti'l-akli'lmücerred adlı risâlede Devvânî sadece risâleyi şerh etmemiştir, bunun yanında meseleye Tûsî'den farklı bakış açıları da getirmiştir.

1. oturumun ardından Salon 3'te gerçekleştirilen ve başkanlığı Doç. Dr. Ferruh Özpilavcı tarafından yapılan oturumda yer alan üç bildiri de mantık ilmi ile ilgiliydi. Yrd. Doç. Dr. Harun Kuşlu, “Gelenbevî’ye Nispet Edilen Mevzûu'l-mantık Risâlesi" başlı̆̆ını taşıyan bildirisine, niçin "Gelenbevî'nin Mevzûu'l-mantık Risâlesi" değil de mezkûr başlı̆̆ı verdiğini izah ederek başladı. Kuşlu'ya göre risâle Gelenbevî'ye nispet edilse de risâle içerik ve üslup açısından aidiyet noktasında bazı şüpheler barındırmaktadır. Yaptığı araştırmalardan bir netice alamadığından bahseden Kuşlu, risâleye ilişkin daha detaylı araştırmaların yapılmasının gerekliliğine işaret etti. Bununla birlikte ona göre risâle ister Gelenbevî́ye ait olsun ister olmasın sonuç olarak mantığın konusuna ilişkin önemli bir risâledir. Kuşlu, risâlenin aidiyetine ilişkin değerlendirmelerinden sonra mantığın konusuna dair tartışmaların tarihi seyrini serdetti. Buna göre mantığın konusu ilk olarak İbn Sînâ tarafından ikinci akledilirler olarak belirlenmiş ve mantık müstakil bir ilim olarak değerlendirilmeye başlanmıştır. İbn Sînâ'nın bu yaklaşımına yaklaşık iki asır sonra gelen Hûnecî itiraz etmiş ve mantığın konusunun "tasavvur ve tasdikle ilgili malumat" olduğunu söyleyerek İbn Sînâ'nın tezine bir antitez ileri sürmüştür. İbn Sînâ'nın ve Hûnecî’nin bu görüşleri mantıkçılar arasında bir gruplaşmaya neden olmuştur. Hûnecî'nin mantığın konusuyla ilgili yeni teklifi Ebherî, Urmevî ve Kâtibî gibi mantıkçılar tarafından kabul görürken Nasîruddîn Tûsî ve Kutbüddîn er-Râzî gibi mantıkçılar tarafından da reddedilmiştir.

Gelenbevî bu iki grubun görüşlerini söz konusu risâlede ele almış ve bu görüşlere karşı itirazları değerlendirmiştir. Kuşlu, Gelenbevî’nin Burhân ve İsâgîû şerhlerinde mantığın konusunun "tasavvvur ve tasdik ile ilgili malumat" olduğu yönünde çok açı bir görüşü olmasına rağmen bu risâlede açıcça ve vurgulayarak bir görüş belirtmediği için risâlenin otantikliği hususundaki problemin hala karşımızda durmakta olduğunu vurgulayarak bildirisini nihayete erdirdi. Yrd. Doç. Dr. Harun Kuşlu'dan sonra Yrd. Doç. Dr. Necmettin Pehlivan, "Şemsud-dîn es-Semerkandî'nin Risâle fî âdâbî'l-bahs'1ndaki Mûcibun Bi'z-Zât-Fâilun Bi'l-İhtiyar Tartışmasına Cârullah Veliyyüddin Efendi'nin Yaklaşımı" başlıklı sunumunu gerçekleştirdi. Bir tartışma teorisi olan Adâbu'l-bahs ve'l-münâzara'nın Semekandî tarafından sistemleştirildiğini ifade ederek bildirisine başlayan Pehlivan bu geleneğe birçok müellifin de yazdıkları şerh ve hâşiyelerle katkıda bulunduklarını belirtti. Pehlivan bu geleneğe katkı yapanlardan birinin de Cârullah Veliyuddin Efendi olduğunu 
ifade ettikten sonra düşünürün bu geleneğe katkısının telif eserlerden ziyade hâşiye türü eserler aracılığıyla olduğunu belirtti. Cârullah Efendi, es-Semerkândî'nin Risâle fî Âdâbi'l-Bahs'ının önemli şârihlerinden biri olan Mes'ûd eş-Şirvânî'nin şerhine 524 varaklık devasa bir hâşiye yazmıştır. Yine Osmanlı bilim havzasında yazılmış telif eserlerden biri olan Hüseyniyye adıyla meşhur olmuş metne yazdığ 1 hâşiye de 220 varaktan oluşmaktadır. Aslen bir kelâmî problem olan 'Mûcibun Bi'z-Zât-Fâilun Bi'1-İhtiyâr' tartışması âdâb geleneğine örnekler üzerinden girmiştir. Pehlivan’a göre oldukça geniş hacimlerine rağmen Cârullah Efendi'nin söz konusu hâşiyelerin Mûcibun Bi'z-Zât-Fâilun Bi'l-İhtiyâr tartışmasına özgün anlamda en azından şu ana kadarki çalışmalar temelinde çok önemli bir katkısının olduğunu söylemenin mümkün olmad1ğını belirterek bildirisine son verdi. Oturumun son konuşmacısı ise "Kilisli Hocazâde Mehmed Tâhir Efendi'nin Modal Kiyas Risalesi: Zübde-i muhtelitât mine't-tasdîkât" başlıklı sunumu gerçekleştiren Arş. Gör. Muhammed Çelik'ti. Çelik söz konusu risâlenin 19. yüzyılda kaleme alındığını belirterek konuşmasına başladı. Risâlenin yazım amacının mantığın oldukça zor konularından biri olan modalite konusunun anlaşılmasını kolaylaştırmak olduğunu söyleyen Çelik'e göre risâlenin bu anlamda modalite tartışmasına yönelik yeni bir yaklaşımı yoktur. Ancak eserin modaliteye ilişkin Türkçe kaleme alınan ilk eser olması ve pedagojik endişelerle örneklerin değiştirilip, çeşitlendirilmesi risâleyi önemli kılmaktadır. Çelik'in bildirisinin en ilginç tespitlerinden bir tanesi, risâle yazarı Mehmet Tahir Efendi, dedesi Mantıkî Hacı Ömer Efendi, babası Hocazâde Abdurrahman Efendi ve ağabeyi Mantıkçı Hocazâde Abdullah Enverî ile birlikte oluşturduğu geleneğin, "Kilis Mantık Okulu” olarak literatürde yer aldığına ilişkin tespitidir.

Başkanlığını Prof. Dr. Gürbüz Deniz'in yaptığı ilk günün son oturumu Prof. Dr. İlhan Kutluer'in sunumuyla başladı. Dinleyicilere "İnsanın Toplumsal Doğası: Klasik Osmanlı Düşüncesinde Medenî bi't-tab' ve Temeddün Terimlerinin Kavramsal Çerçevesi" başlıklı bildirisini sunan Kutluer, bildirisinde klasik ahlak, siyaset ve tarih kitaplarında insanın toplumsal bir varlık oluşuna yapılan vurgunun Osmanlı düşünce geleneğinde de devam ettiği tespitini yaptı. Medenî bi't-tab ve temeddün kavramlarını Molla Lütfi, Tursun Bey, Kınalızâde Ali, Taşköprülüzâde gibi Osmanlı düşünce geleneğinin temsil gücü yüksek isimleri tarafından nasıl ele alındığına değindi. Kutluer'den sonra Doç. Dr. Fatih İbiş bildirisini sundu. "Osmanlı Düşüncesinin Köklerini Saldığı Toprak-Taşköprülüzâde Üzerinden Bir Okuma" başlıklı tebliğinde İbiş, Descartes'in köklerini metafiziğe, gövdesini fiziğe ve dallarını da mekanik ve etiğe benzettiği ağaç örneğine ilişkin, Heideger' in bu ağacın hangi toprakta yetiştiğine dair sorusundan hareket ederek Taşköprülü'nün Miftâhu'sSaadet adlı eserini yorumladı. Taşköprülü'nün eseri ile Descartes'in felsefe ağacı arasındaki benzerliğe ilişkin yaklaşımı ve Heidegger'in sorusuna cevap

Journal of Sakarya University Faculty of Theology (SAUIFD), Volume: XIX, Issue: 36 (December 2017) 
olarak bu ağacın varlık üzerinde yükseldiğini söylemesi ilginç tespitlerdendi. Oturumun üçüncü konuşmacısı olan Yrd. Doç. Dr. Kenan Tekin, “Osmanlı Dönemi Bilim Felsefesinin Mahiyeti ve Kaynakları" başlıklı bildirisinde Osmanlı döneminde bilim felsefesinin mahiyetini ve kaynaklarını ele aldı. Tekin'e göre bilimler farklı meselelerden oluşur ve o meseleleri bir tek bilim adı altında toplayan bir cihet-i vahde yani birlik yönü vardır. Genel olarak zâtî ve arazî olmak üzere iki tür birlik yönüne vurgu yapılmıştır. Bir bilimin mevzusu onun zâtî birlik yönünü oluşturur, gayesi de onun arazî birlik yönünü oluşturur. Tekin'e göre cihet-i vahde mevzusu o dönemli Osmanlı bilim felsefesinin ayırt edici niteliğini oluşturur. Dolayısıyla bu anlamda modern dönemde ortaya çıkan bilim felsefesi ile önemli benzerlikler barındırsa da ciheti vahde Osmanlı bilim felsefe geleneğinin, neyin bilimin konusu olduğuna/olmadığına ilişkin özgün bir çözüm önerisidir. Oturumun son konuşmacısı olan ve "Osmanlı Düşüncesinin Metafizik Altyapısını Oluşturan Disiplinler Olarak Kelâm Felsefe ve Tasavvuf: Kemalpaşazâde ve Risâleleri Üzerinden Bir İnceleme" başlıklı bildirisini sunan Arş. Gör. Bilal Taşkın, bildirisinde Osmanlı düşüncesinin dayandığı bu üç temel disiplini inceledi. Bu temeli din, akıl ve irfânî olarak üç epistemolojik temele ayıran Taşkın, bu üç temelin sırasıyla kelâma, felsefeye ve tasavvufa denk geldiği tespitini yaptı ve bu üç disiplinin Osmanlı düşüncesi içerisindeki konumunu Kemalpaşazâde'nin risâleleri üzerinden inceledi.

İkinci günün ilk oturumunun başkanlığını Prof. Dr. Hatice Kelpetin Arpaguş yaptı. Oturumun ilk konuşmacısı Doç. Dr. Osman Demir'di. Demir, “Osmanlı'da Kozmoloji Tartışmaları: İbn Kemal'in Tafra Risâlesi Bağlamında Bir İnceleme" başlıklı bildirisinde ilk olarak Tafra teorisinin İslam düşüncesindeki serencâmını ortaya koydu. Ardından İbn Kemal'in Risâle fì beyâni'ttafra adlı eserini söz konusu konu bağlamda ele aldı. Demir'den sonra Yrd. Doç. Dr. Hülya Terzioğlu, "Devvânî̀nin İsbat-1 Vâcib Risâlesi ve Osmanlı Kelâm Düşüncesine Etkisi" başlıklı bildirisini sundu. Bildirisinde ilk olarak Devvâni'nin İsbât-1 Vâcib anlayışına temas eden Terzioğlu ardından söz konusu anlayışın Osmanlı düşünürleri tarafından nasıl tevarüs edildiğini inceledi. Oturumun üçüncü konuşmacısı Arş. Gör. Dr. Ayşe Betül Tekin'di. “Osmanlı Kelâm Literatüründe Temel Bir Kaynak: Cürcânî'nin Hâşiyetü'tTecrîl' ${ }^{\prime}{ }^{\prime \prime}$ başlıklı bildirisini sunan Tekin, konuşmasının başında Tûsî'nin Tecrîdü'l-itikâd adlı eserine ilişkin oluşan literatüre dikkat çekti. Ardından mezkûr eserin Osmanlı düşünce dünyasındaki etkisine örnekler üzerinden değindi. Oturumun son sunumu ise Arş. Gör. Mustafa Bilal Öztürk'ün “Hatibzâde-i Rûmî ve Risâle fì isbâti'r-rü'ye ve'l-kelâm Adlı Eseri" başlıklı sunumuydu. Kelâm literatüründe oldukça canlı bir tartışma olan Allah'ın kelâmı ve görülmesi üzerine Hatibzâde tarafından müstakil bir eser olarak yazılan mezkûr risâleyi dinleyiciye sunan Öztürk, risâleyi kelâm geleneğinin temel 
eserleri olarak kabul edilen Makâsıd ve Mevâkıf gibi eserler ve bunlara yazılan şerh ve hâşiyeler bağlamında yöntem, içerik ve bulgular yönünden ele aldı.

II. oturumun başkanlığını Prof. Dr. Süleyman Akkuş icra etti. Akkuş'un başkanlığında gerçekleştirilen bu oturumun ilk tebliği bir önceki oturumun başkanlığını yapan Prof. Dr. Hatice Kelpetin Arpaguş'a aitti. "Mâtüridîlik ve İrâde-i Cüz'iyye'nin Osmanlı'daki Görünümü” başlıklı bildirisinde Arpaguş, ilk olarak Mâtürîdî gelenekte cüz-i irâdeye ilişkin yaklaşımlardan bahsetti. Ardından bu meselenin Osmanlı düşüncesindeki görünümünü Beyâzizâde Ahmed Efendi, Davud-1 Karsî, Akkirmânî, Hâdimî, Esîrizâde Abdülbakî Efendi gibi Osmanlı müellifleri üzerinden değerlendirmeye tabi tuttu. Oturumun ikinci sunumunu "Şerhu'l-Akâid ve Osmanlı Düşüncesi Açısından Değeri” başlıklı bildirisiyle Yrd. Doç. Dr. Harun Çağlayan gerçekleştirdi. İlk olarak İslam kelâm düşüncesinin temel eserlerinin başında gelen mezkûr eser üzerine oluşan literatürden bahseden Çağlayan, sunumunun geri kalanında bu eserin Osmanlı düşüncesindeki etkisini eser üzerine yazılan şerhler ve hâşiyeler üzerinden gösterdi. Çağlayan'ın Şerhu'l-Akâid'in temelde özgün bir eser olmadığı halde hem İslam kelâm geleneğinde hem de Osmanlı müellifleri üzerinde büyük bir etkiye sahip olmasını pedagojik açıdan meseleleri anlaşılır, muhtasar ve sistematik biçimde özetlemesine bağlaması ilginç bir tespit olarak dikkat çekti. Çağlayan'dan sonraki sunumu Arş. Gör. İmam Rabbani Çelik gerçekleştirdi. “XV. Asır Osmanlı Entelektüel Çevresi İçin Teftâzânî Ne İfade Eder?: Hâşiye Literatüründe Otorite İsim Olarak Teftâzânî" başlığını taşıyan sunumda Çelik ilk olarak Osmanlı entelektüel çevresi ile neyi kastettiğini açıkladı. Çelik'e göre XV. asır Osmanlı düşüncesi açısından entelektüel bir çevrenin oluşmaya başladığı dönem olarak kabul edilebilir. Bu dönemden sonra okunan ve okutulan eserler bir hiyerarşiye kavuşmuş ve sistemleşmiştir. Bu tespitlerin ardından Çelik, Teftâzânî'nin Şerhu'l-Akâid ve Şerhu'lMakâsıd başta olmak üzere Telvîh ve Mutavvel gibi diğer eserlerin Osmanlı'ya geçiş sürecini yazma nüshalar üzerinden tarihlerini de dikkate alarak ele aldı. Özellikle söz konusu eserlerin yazılış tarihlerinden kısa bir süre sonra Osmanlı kütüphanelerinde ve medreselerinde yerini alması, Teftâzânî'nin Osmanlı düşünce hayatında etkisini ortaya koyması açısından Çelik tarafından ifade edilen oldukça önemli bir tespitti. Oturumun son bildirisi ise Arş. Gör. Mehmet Fatih Arslan'a aitti. “Osmanlı'da Kelâm-Felsefe Etkileşimi: Sıfatların İmkânı ve Kıdemi Bağlamında Şerhu'l-Akâid Geleneği” başlıklı tebliğinde Arslan, ilk olarak Şerhu'l-Akaid üzerine oluşmuş literatürden bahsetti. Ardından söz konusu meseleyi Mûsâ Hayâlî, Mustafa el-Kastalânî, Ramazan b. Muhammed ve Muhammed Siyalkûtî gibi âlimlerin Şerhu'l-'Akâid'e yazdıkları şerhler ve hâşiyeler bağlamında tartıştı. Arslan tartışmasını ilk dönem kelâmcılarında görülmeyen Tanrı'nın sıfatlarının zâtının ne aynı ne de gayrı olduğu anlayı- 
şının, felâsifenin varlık anlayışının etkisi dolayısıyla ortaya çıktığı iddiası üzerinden yürüttü. Arslan'ın sunumunda bahsi geçen eserlerin ilgili kısımlarını projeksiyon cihazı vasıtasıyla dinleyiciyle paylaşması sunum tekniği açısından ilgi çekiciydi.

İkinci günün III. oturum başkanlığını Prof. Dr. Gürbüz Deniz yürüttü. Oturumun ilk tebliği "Öne Çıkan Konuları İtibariyle Osmanlı Dönemi Müstakil Fâtiha Sûresi Tefsirleri" başlıklı sunumuyla Yrd. Doç. Dr. Şükrü Maden'e aitti. Tebliğine Osmanlı tefsir geleneğinde tam tefsirlerin oldukça az olduğu tespitiyle başlayan Maden, çeşitli sebeplere dayalı olarak Osmanlı âlimlerinin daha çok tefsir hâşiyesi ya da sûre ve âyet tefsirleri yazmayı tercih ettiklerini belirtti. Üzerine en çok tefsir yazılan sûrenin Fatiha sûresi olduğu tespitini yapan Maden, sunumun devamında Molla Fenârî, Molla Hüsrev, Cemâl Halvetî, Bayezid Halife, İbn Kemal, Aziz Mahmud Hüdâyî, İsmail Ankaravî gibi âlimlerin Fatiha sûresine ilişkin tefsirlerine değindi. Yrd. Doç. Dr. Şükrü Maden'den sonra Yrd. Doç. Dr. Harun Abacı sunumunu gerçekleştirdi. “Osmanlı Dönemi İ'râbü'l-Kur'ân Literatürü Üzerine" başlığını taşıyan tebliğinde Abacı ilk olarak I'râbu'l-Kur'ân'ın ne anlama geldiğini ardından da bu konu üzerine Osmanlı tefsir geleneğinde oluşan literatürden bahsetti. Osmanlı tefsir geleneğinde en çok Besmele ve Kelime-i Tevhid'in i'râbu'l-Kur'ân'a konu olduğunu belirten Abacı, sunumunun devamında bu gelenek içerisinden seçtiği müfessirlerin Besmele ve Kelime-i Tevhid'i söz konusu yöntemle nasıl tefsir ettiklerini karşılaştırmalı olarak dinleyicilerle paylaştı.

Başkanlığını Doç. Dr. Mustakim Arıcı'nın yaptığı IV. oturumda Osmanlı ahlak düşüncesi denildiğinde ilk akla gelen düşünür olan ve Ahlâk-ı Alâî müellifi Kınalızâde Ali Çelebi üzerine yazılan iki tebliğ sunuldu. İlk sunum K1nalızâde ve Ahlâk-ı Alâî üzerine yaptığı çalışmalarla bilinen Doç. Dr. Ayşe S1dıka Oktay'a aitti. "Kınalızâde Ali Efendi'nin Ahlâk-ı Alầ'sinde Yer Alan Tartışma Konuları" başlıklı sunumuna Kınalızâde'nin hayatı ile başlayan Oktay, sunumunun devamında Ahlâk-ı Alầ' nin içeriğinden hareketle iman amel ilişkisi, müzik, şiir dinleme ve söylemenin hükmü gibi konularda Kınalızâde'nin görüşlerini ele aldı. Oktay'ın ardından yine Ahlâk-ı Alâî üzerine yaptığı çalışmalarla tanınan bir diğer akademisyen Doç. Dr. Murat Demirkol, "Kınalızâde Ali Çelebi'nin Ahlak Felsefesine Katkısı" başlıklı sunumunu gerçekleştirdi. Demirkol sunumun başında Ahlâk-ı Alâî'nin beslendiği kaynakları (Tehzîbü'lahlak, Ahlâk-ı Nâsırî ve Ahlâk-ı Celâlî) zikretti ve bu kaynaklardan hangi yönleriyle ayrıldığına değindi. Demirkol'a göre Kınalızâde bu kitapta, beslendiği diğer ahlak eserlerini muhteva ve öz itibarılla muhafaza etmenin yanı sıra, eserine edebî letafet katmış, hikâye ve örneklerle öğrenimi kolaylaştırmış, özellikle nefis hastalıklarının tedavisinde Gazzâlı̂'den, sevgi konusunda Molla Câmî'den yararlanmıştır. Ahlâk-ı Alâı̂'de Kınalızâde kendisinden önceki müellifleri yer yer tenkit etmiş, problemlere özgün açıklamalar vermiştir. 
Bunlara ek olarak eserin Türkçe olarak kaleme alınmış olması da eseri gelenekteki diğer eserlerden ayıran bir başka hususiyet olarak öne çıkar.

Oturum değerlendirmelerinden sonra sempozyumun geneline ilişkin bir değerlendirme yapmak gerekirse, göze çarpan en önemli eksikliğin, bildirilerin bilim alanlarına göre dağılımındaki heterojenlik olduğu söylenebilir. Her ne kadar çağrı metninde sempozyumun Osmanlı düşünce geleneğini oluşturan tüm alanları kapsamayı amaçladığı ifade edilse de sempozyumda sunulan bildiriler daha çok Osmanlı düşüncesinin felsefe, kelâm, tasavvuf, siyaset, ahlak, hadis, tefsir gibi alanlarla ilgiliydi. Bu alanların dışında kalan dil, tarih, edebiyat, sanat, mimari, şehircilik gibi alanların eksikliği dikkati çekmektedir. Bu durumun en temel nedeni eksikliği hissedilen alanların teorisine ilişkin araştırmaların yok denecek kadar az olmasıdır. Eksikliği hissedilen alanlar açısından Dr. Gökhan Demir'in "Kudsî'nin Hüsnü's-sülûkfî şâni'l-mülûk (Şerh$i$ hadîs-i erbần) Adlı Eseri" başlıklı bildirisi sempozyumda edebiyat alanındaki tek bildiri olmasıyla dikkat çekti.

Sempozyum bildirileri açısından bir başka sorun da ahlak alanı ile ilgiliydi. Osmanlı ahlak düşüncesine dair sunulan iki bildiri de Ahlâk-ı Alât’ye dairdi. Her ne kadar aynı oturumda Arş. Gör. Seda Ensarioğlu'nun "Ahlâk Eserlerinde Dönemi Okumak: Kemalpaşazâde Mehmed Saîd Üzerine Bir İnceleme" başlıklı bildirisi yer alsa da kendisi sempozyuma katılamadığı için dinleyiciler bildiri ile ilgili fikir edinemedi. Osmanlı ahlak düşüncesi denildiğinde sürekli olarak Kınalızâde'nin ve eseri Ahlâk-ı Alâı̂'nin ön plana çıkması, bu alanda başka müellif ve eser olmadığı izlenimini uyandırdı. Ayrıca oturum başkanı Doç. Dr. Mustakim Arıcı'nın oturuma ilişkin müzakeresinde Kınalızâde'nin ahlak düşüncesinin tek eserden hareketle ortaya konulmasının, diğer eserlerini dikkate almamanın yanlış olacağına ilişkin uyarısı oldukça önemliydi. Dolayısıyla Doç. Dr. Ayşe Sıdıka Oktay ve Doç. Dr. Murat Demirkol gibi Osmanlı ahlak düşüncesi üzerine çalışan araştırmacıların artması gerektiği altı çizilmesi gereken bir eksiklik olarak kendisini gösterdi.

$\mathrm{Bu}$ eksikliklerin yanında sevindirici gelişmelerin olduğunu da söylemek gerekir. Özellikle felsefe, kelâm, tasavvuf, siyaset alanlarında ikişer oturumun düzenlenmesi bu alanlarda Osmanlı düşüncesine ait bazı soruların cevaplanmasına yaklaşıldığının bir işareti olarak yorumlanabilir.

Bir diğer sevindirici gelişme ise sempozyumda sunulan 51 tebliğin neredeyse 3/4'ünden fazlasının oldukça genç yaştaki akademisyenler tarafından hazırlanmış olmasıdır. Bu araştırmacıların neredeyse tamamına yakınının çalışma alanı olarak kendilerine Osmanlı düşüncesini seçmeleri önümüzdeki yıllarda hem nicelik hem de nitelik açısından ortaya çıkacak oldukça değerli çalışmaların habercisi olarak görülebilir. 
Sonuç olarak büyük bir emekle böylesi bir sempozyumu gerçekleştiren OSAMER müdürü Prof. Dr. Fuat Aydın ve onun şahsında düzenleme ve bilim kurulunda yer alan akademisyenler, katılımciların sorunsuz bir sempozyum geçirmesi için tüm gayretleriyle çalışan görevliler ve sempozyumun gerçekleşmesine maddi ve manevi katkı veren kurum ve kuruluşlar takdiri ve büyük bir teşekkürü hak etmektedirler. 